\title{
SEASONAL VARIATION OF WATER CHARACTERISTICS IN KUALA SIBUTI RIVER ESTUARY IN MIRI, SARAWAK, MALAYSIA
}

\author{
Saifullah A. S. M.*, Abu Hena M. K., Idris M. H.,Rajaee A.H. and Johan I. \\ ${ }^{1}$ Department of Animal Science and Fishery, Faculty of Agriculture and Food Sciences, Universiti Putra \\ Malaysia Bintulu Sarawak Campus, Nyabau Road, P.O. Box 396, Bintulu 97008, Sarawak, Malaysia \\ *Corresponding author: saifullahasm@yahoo.com
}

\begin{abstract}
This paper presents the water characteristics of Kuala Sibuti river estuary, which is margined by pristine mangrove forest. For this purpose, nutrients, chlorophyll $a$ and environmental parameters were investigated for 12 months. Physical, chemical and biological parameters of this estuarine water followed a seasonal rhythm and induced by the annual cycle of the monsoon. Surface water temperature ranged from $27.4^{\circ} \mathrm{C}$ to $32.2^{\circ} \mathrm{C}$ with a wide variety of salinity from $0.70 \mathrm{PSU}$ to $27.10 \mathrm{PSU}$ followed by Dissolved Oxygen (DO) from 1.94 to $6.71 \mathrm{mg} / \mathrm{L}$. The concentration of chlorophyll $a$ was found to be varied from 0.02 to $0.16 \mathrm{mg} / \mathrm{m}^{3}$. Nitrate, phosphate and ammonium concentrations ranged from 0.40 to $3.53 \mathrm{mg} / \mathrm{L}, 0.01$ to $1.92 \mathrm{mg} / \mathrm{L}$ and 0.06 to 1.24 $\mathrm{mg} / \mathrm{L}$, respectively. Pearson correlation coefficients showed a significant relationship between nitrate and TDS, nitrate and $\mathrm{pH}$, ammonium and salinity, temperature and salinity, temperature and TDS, phosphate and light attenuation in this estuarine environment. The estuary was found to be mesohaline in nature. Estuarine Water Quality Index (EWQI) calculated from phosphate $\left(\mathrm{PO}_{4}\right)$, suspended matter $(\mathrm{SM})$ and dissolved oxygen (DO) indicate very good quality (4.95). Significantly seasonal difference for salinity, water temperature and, TDS were observed probably related to tidal flow and upstream river runoff.
\end{abstract}

(Keywords: Estuary, Water characteristics, Nutrients, Chlorophyll $a$, Kuala Sibuti, Sarawak)

\section{INTRODUCTION}

Estuaries are transitional areas between the sea and river water ecosystems. Generally, it is occupied by the combination of freshwater and marine organisms for their feeding, shelter and breeding purposes [1].Estuaries and coasts around the world are the provider of various benefits to the mankind andto the society. They are rich in biological diversity and large in productivity due to their shallowness, protected waters and availability of nutrients derived from different sources [2]. Estuaries and adjoining coastal waters receive inputs of various substances from a wide range of human activities, and for this reason very often they are categorized as 'receiving waters'. The estuary bound rivers can carry substantial loads of nutrients, organic matter and other materials that originate from upstream sources.

Interactions between rivers and floodplains due to flooding can cause major changes of surface water quality in an estuarine environment [3].Besides, estuarine water may be influenced by many other factors like anthropogenic pollution, natural decomposition, etc.In many cases, large urban populations are located close to estuaries, with the results that substances arising from municipal and industrial sources are often discharged directly to these tidal waters. So, for the purpose of evaluating the specific importance there is a clear need for a comprehensive approachon estuarine environmental quality classification. Classification of estuaries takes into account physics, chemistry and biology in one side, and the water column and sediment aspects of the others [4]. There is also an interlinking among physical, chemical and biological factors in estuarine water. Physical parameters of water may influence on dilution of nutrients and finally those nutrients couldhave influence on the distribution and abundance of biota.

In Malaysia, the management of the estuaries and its classification are not well documented. Some studies for recognizing the riverine or marine regime have been conducted byIbrahim et al [5] and few researches on estuarine water quality in different places in Malaysia were conducted so far [6, 7].In 1985, the Department of Environment (DOE), Ministry of Science, Technology and Environment, Malaysia launched an extensive study to develop water quality criteria and realistic standards for the protection and sound management of the nation's finite and vulnerable water resources [8]. However, there is still required more studies to 
get a complete scenario of the estuaries of the country. Hence, it is needed to investigate water characteristics in the estuarine area of Malaysia which could later lead towards formulating a classification guideline for estuaries. Keeping these above in mind, this study aimed to observe the water characteristics and its linkage to nutrients and chlorophyll content in a pristine mangrove estuary in Kuala Sibuti, Miri. Sarawak. The outcome of the research would be able to characterize the Kuala Sibuti river estuary towards formulating a management plan in future.

\section{MATERIALS AND METHODS}

\section{Study Area Location}

This study was conducted in Kuala. Sibuti (KS) river estuary, Miri, Sarawak, Malaysia and located at $113^{\circ} 23^{\prime} 13.4^{\prime \prime} \mathrm{E}$ and $3^{\circ} 37^{\prime} 2.7^{\prime \prime} \mathrm{N}$ in tropical climatic condition. Sampling was done from three stations named as station 1,2 and 3 (Figure 1) from January 2013 to December 2013. The distance within stations was approximately $1 \mathrm{~km}$. Station 1 was situated near the mouth of the river and received neritic water from the adjacent South China Sea with the depth of 3-4 meter. The bank of the Kuala Sibuti (KS) river was covered by mangrove Rhizophora apiculata and Nypa
fruticans.

\section{Collection of Sample and Analysis}

In-situ data for water $\mathrm{pH}$, temperature, salinity, TDS, conductivity and dissolved oxygen (DO) were detected using a water quality meter (WQC-24). Three replicates for each parameter were measured from each station.Water transparency was measured by secchi disc $(30 \mathrm{~cm}$ diameter $)$ and light attenuation coefficient was calculated using the formula $\mathrm{k}=1.7 /($ secchi depth), where $\mathrm{k}$ is the light attenuation coefficient. Corresponding air temperature and rainfall data for the study area were collected from Meteorological Department, Sarawak, Malaysia. For analysis of water, nutrients, three surface water samples were collected in clean polyethylene bottles from each station and were kept in the icebox and transported to the laboratory immediately. The water samples were filtered using Millipore Filtering System (MFS) and analyzed for dissolved inorganic phosphate, nitrate and ammonium $[9,10$ and 11$], \quad$ respectively. Chlorophyll a concentration was estimated following the methods described by Coombs and Hall [12].
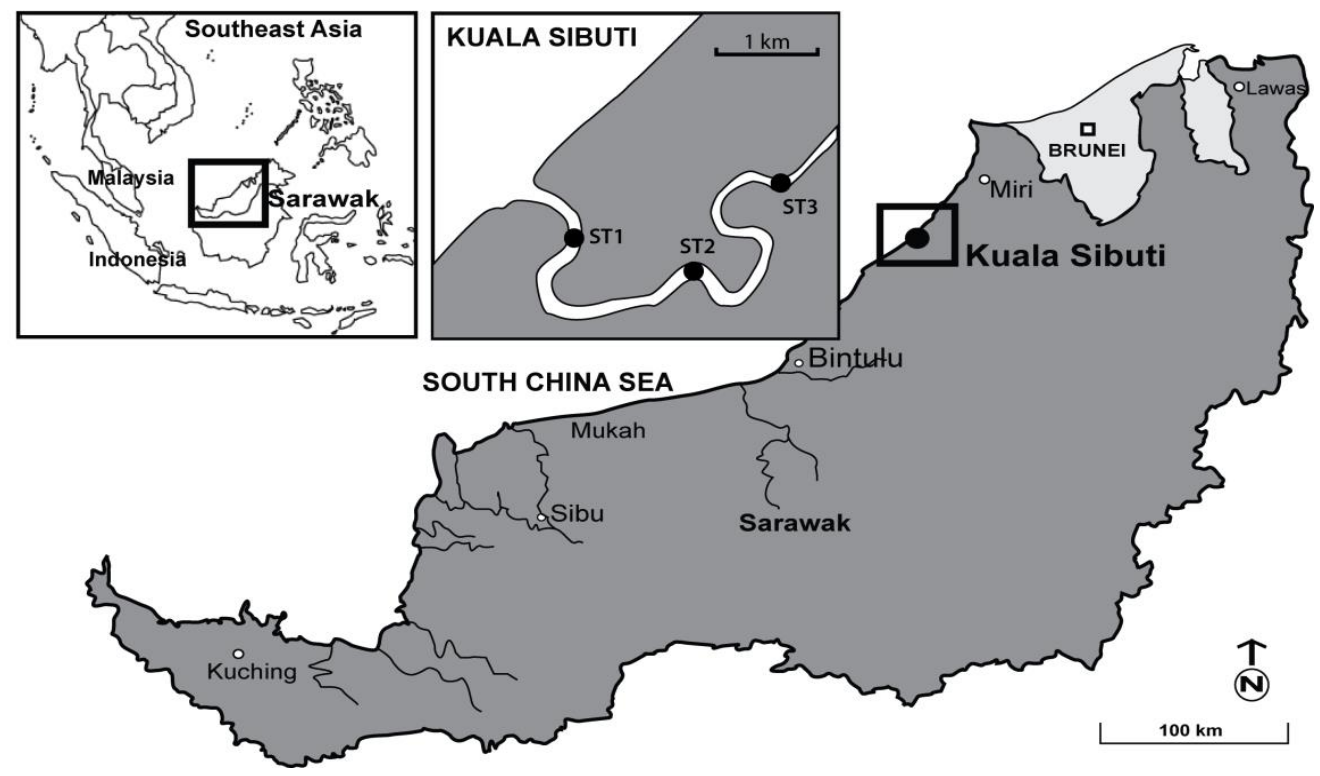

Figure1. Map of the study area showing sampling stations at KS river estuary, Miri, Sarawak. 
Estuarine Water Quality Index (EWQI) was calculated using the concentrations of dissolved oxygen, phosphate and suspended sediment. The index was calculated according to the equation described by Ibrahim et al. [5]: EWQI $=0.495 \mathrm{I}$ $[\mathrm{DO}]+0.289 \mathrm{I}[\mathrm{SM}]+0.216 \mathrm{I}[\mathrm{PO}]$, where I [DO], $\mathrm{I}$ [PO], I [SM] are sub-indices of the parameters like phosphate, dissolved oxygen and suspended matters. The weightings or coefficients for each parameter were based on the United States National Sanitation Foundation's Water Quality Index [13]. The EWQI value ranges from 1 to 5 and above, with a value of 1 indicating very poor quality and a value of 5 and above indicating very good quality. Statistical analysis was performed using SAS 9.1 (portable version) and Canonical Correspondence Analysis was carried out using CANOCO software version 4.50.Analysis of Variance (ANOVA) was conducted using SAS 9.1.

\section{RESULTS}

Rainfall varied from $101.3 \mathrm{~mm}$ to $691.2 \mathrm{~mm}$ with the highest value in December (wet season) and the lowest in August i.e. dry season (Figure 2). Rainfall was observed somehow in every month of the year.

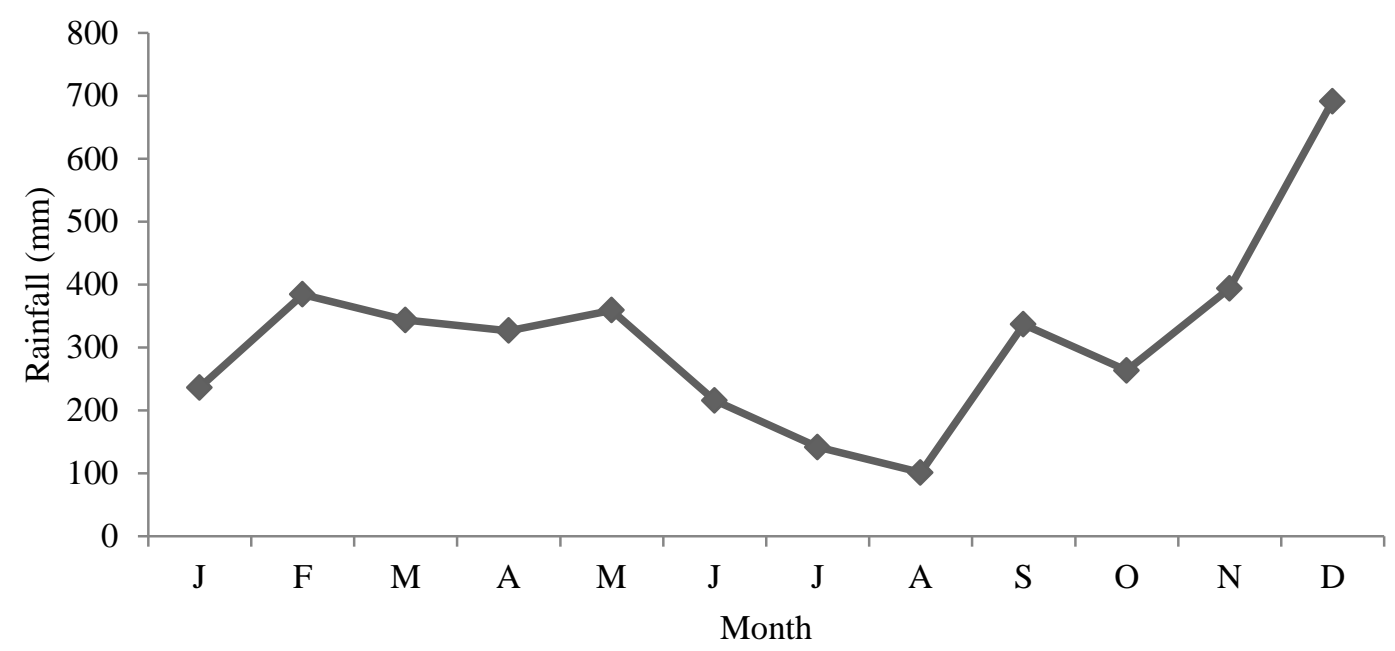

Figure 2.Seasonal variation of mean rainfall in KS during January 2013-December 2013.

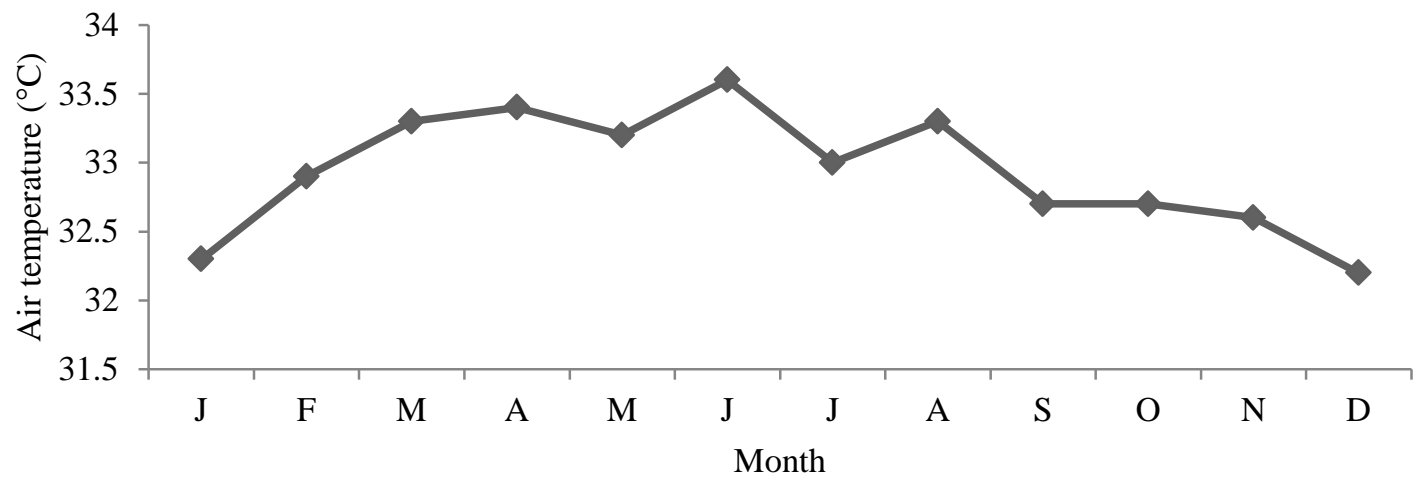

Figure 3.Seasonal variation of mean air temperature at KS, Miri, Sarawak (January 2013-December, 2013). 
The air temperature ranged between $32.2^{\circ} \mathrm{C}$ to $33.6^{\circ} \mathrm{C}$ (Figure3) with the highest value in the month of June $\left(33.6^{\circ} \mathrm{C}\right)$ and the lowest value in the month of December $\left(32.2^{\circ} \mathrm{C}\right)$. The surface water temperature of the estuary ranged from $27.4^{\circ} \mathrm{C}$ to $32.2^{\circ} \mathrm{C}$ with the lowest in the month of January i.e. intermediate season and highest in May i.e. dry season (Figure 4a).
The seasonal variation in the salinity of the estuarine system was large. Salinity ranged from 0.3 PSU (in February i.e. intermediate) to 27.1 PSU (in July, dry season). Salinity was found higher during May to August (dry season) which ranged from 14.97 to 27.1 PSU and dropped abruptly from September and fluctuated in between 0.3 to 10.3 PSU till April.

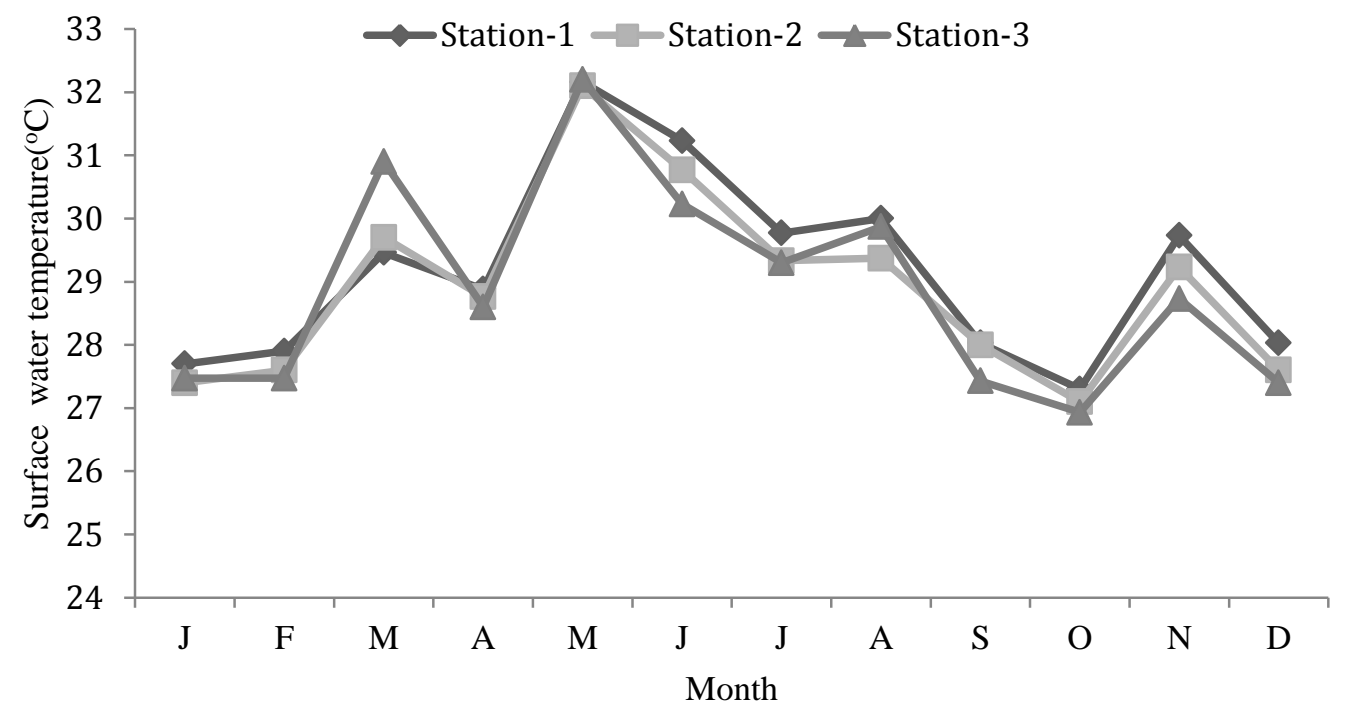

Figure 4a.Seasonal variation of surface water temperature $\left({ }^{\circ} \mathrm{C}\right)$ at $\mathrm{KS}$ river estuary, Miri, Sarawak.

This showed an increasing trend from January and reached the highest in May and started lowering again towards December with slight fluctuation.
The low salinity was founded in February (intermediate season) which was only 0.3 PSU(Figure 4b).

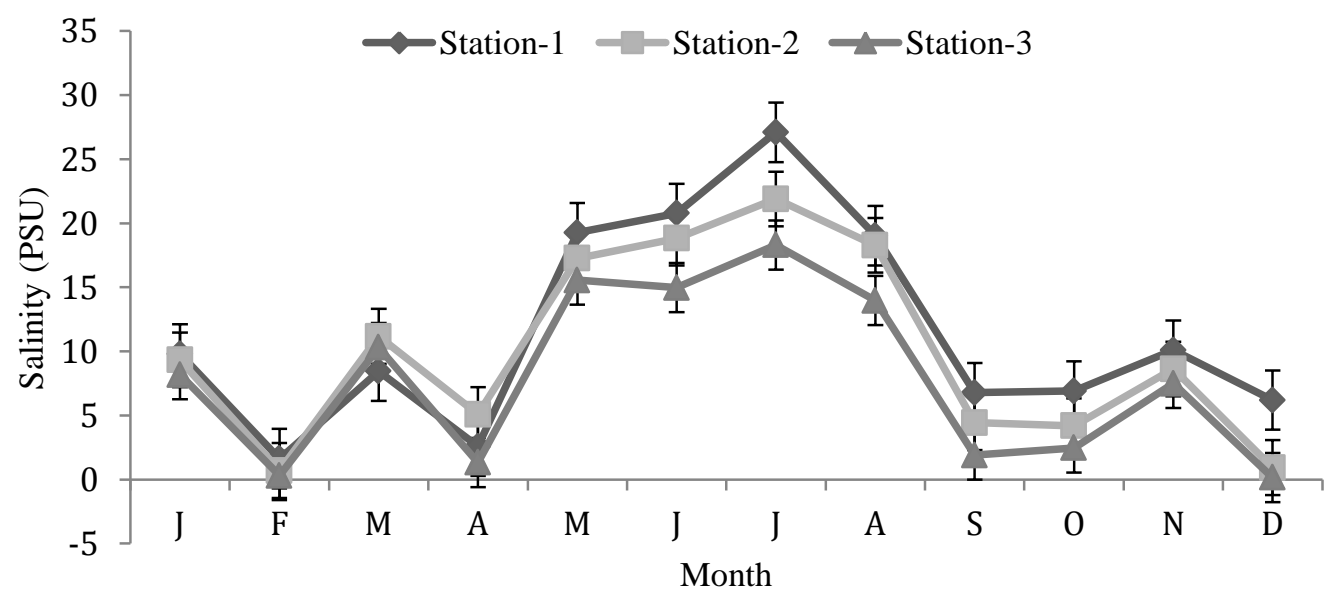

Figure 4b.Seasonal variation of salinity $( \pm$ SE) in the KS river estuary, Miri, Sarawak. 
The seasonal distribution of dissolved oxygen (DO) concentration in each station is shown in Figure 4c. Dissolved oxygen ranged from 1.94 to $6.71 \mathrm{mg} / \mathrm{L}$ and the lowest $(1.94 \mathrm{mg} / \mathrm{L})$ was found in the month of June in station 3 and maximum was found in September in Station1 (Figure 4c). The highest value of DO was found in the month of September and the lowest in the month of April.

The values of $\mathrm{pH}$ were found slightly acidic to alkaline (4.41 to 7.35$)$. The lowest value was observed in the month of February in station 3 and the highest value was in the month of August in station 1 (Figure4d).
The total dissolved solids (TDS) showed a temporal variation which ranged from 8.63 to 146.4 NTU (Figure 4e). The highest TDS was found in the month of February (146.4 NTU) followed by December in station 1 (118.4 NTU) and July (114.27NTU) in station 1 (Figure 4e).

Light attenuation coefficient calculated from secchi disc depth showed seasonal variation (Figure 5). Light attenuation was found highest in February i.e. in intermediate season (0.07) and lowest in May i.e. in dry season (0.02).

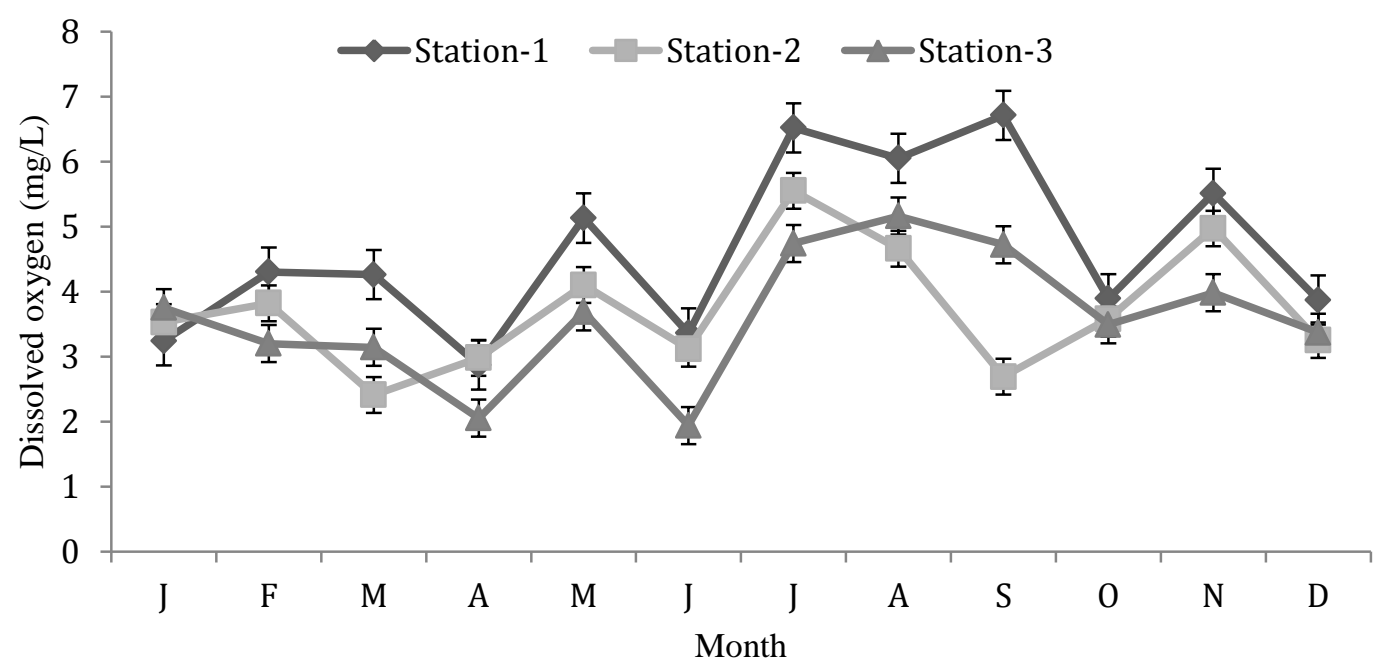

Figure 4c.Seasonal variation in Dissolve oxygen $( \pm \mathrm{SE})$ at KS river estuary, Miri, Sarawak.

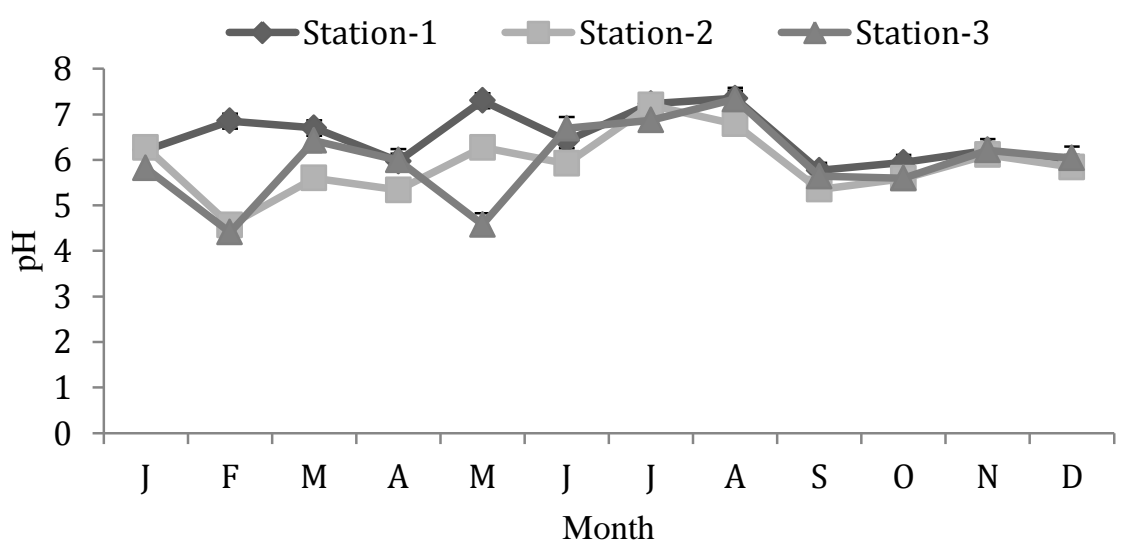

Figure 4d.Seasonal variation in $\mathrm{pH}( \pm \mathrm{SE})$ at KS river estuary, Miri, Sarawak. 


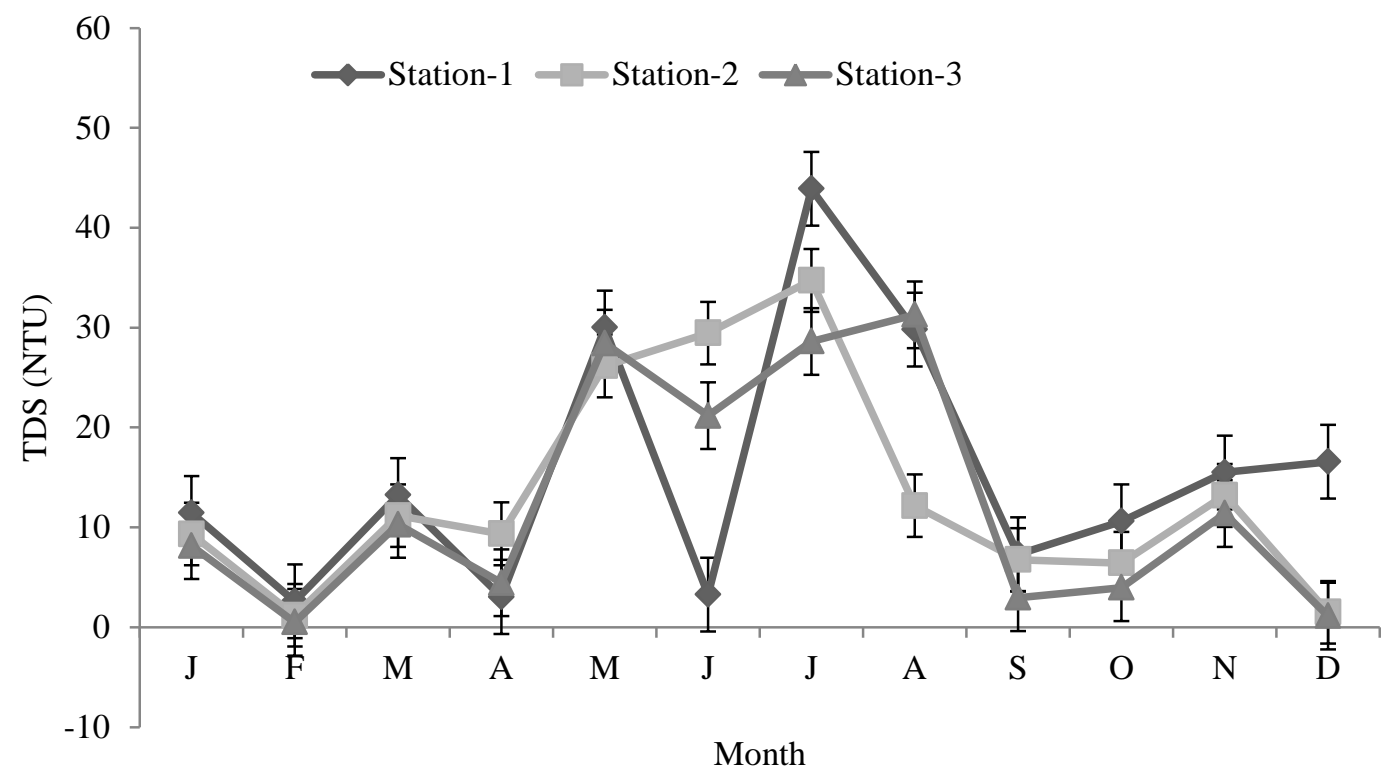

Figure 4e. Seasonal variation of total dissolved solids $( \pm$ SE) atKS river estuary, Miri, Sarawak.

The Chlorophyll $a\left(\mathrm{mg} / \mathrm{m}^{3}\right)$ concentration varied in terms of temporal and spatial context. In station1, the concentration ranged from 0.02 to $0.16 \mathrm{mg} / \mathrm{m}^{3}$ with a minimum in February and maximum in the month of July (Figure 6). The content of Chlorophyll $a$ was found higher in station 2 than that of station 1 and it ranged from 0.01 to 0.21 $\mathrm{mg} / \mathrm{m}^{3}$ and the lowest was found in the month of December and highest in the month of April. The lowest concentration of chlorophyll awas found in station 3 with a range from 0.01 to $0.14 \mathrm{mg} / \mathrm{m}^{3}$, with minimum in December(wet season) and maximum in June (dry season).

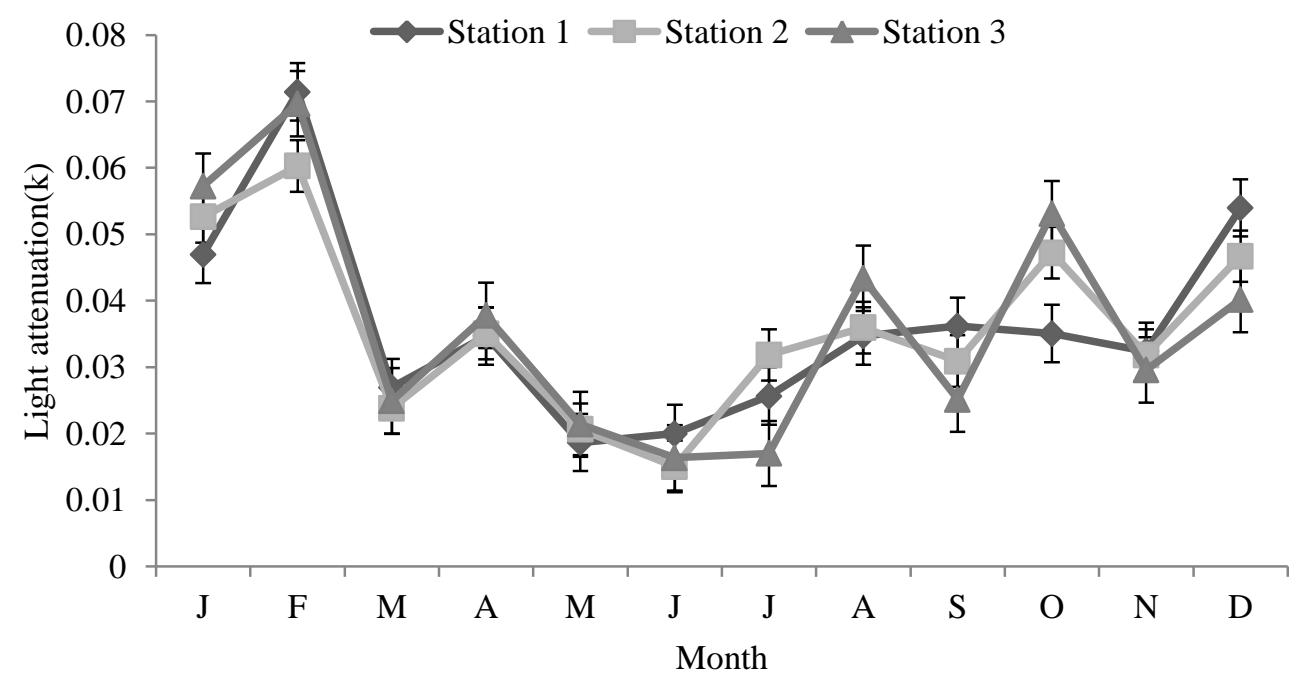

Figure 5.Seasonal variation of light attenuation coefficient $( \pm$ SE)at KS river estuary, Miri, Sarawak. 


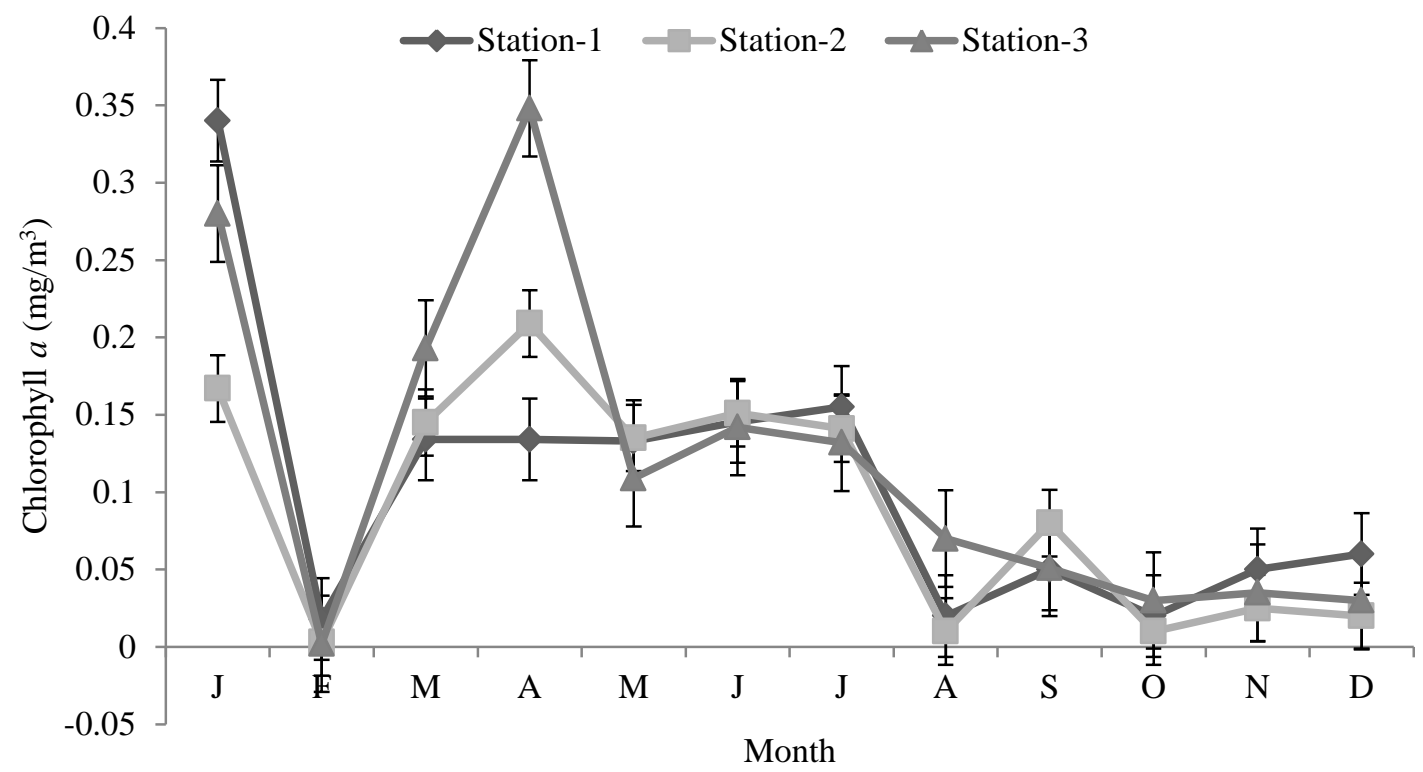

Figure 6.Seasonal variation of Chlorophyll $a( \pm$ SE)at KS river estuary, Miri, Sarawak.

The concentrations of nutrients, i.e., nitrate, phosphate and ammonium showed seasonal variation (Figure7a-c). Nitrate concentration ranged from $0.4 \mathrm{mg} / \mathrm{L}$ to $3.53 \mathrm{mg} / \mathrm{L}$ and the lowest concentration of nitrate was found in the month of March in station 1 and higher in the month of September (i.e. Wet season)in station3.Phosphate concentration ranged from $0.01 \mathrm{mg} / \mathrm{L}$ to $1.92 \mathrm{mg} / \mathrm{L}$. The lowest concentration was found in the month of
September (wet season) in station 1 and the maximum was observed in February(intermediate season) in station 3. The concentration of ammonium ranged from $0.06 \mathrm{mg} / \mathrm{L}$ to $1.24 \mathrm{mg} / \mathrm{L}$. The lowest value was found in the month of February, i.e. intermediate season $(0.01 \mathrm{mg} / \mathrm{L})$ and the highest was recorded in the month of July i.e. dry season $(1.24 \mathrm{mg} / \mathrm{L})$.

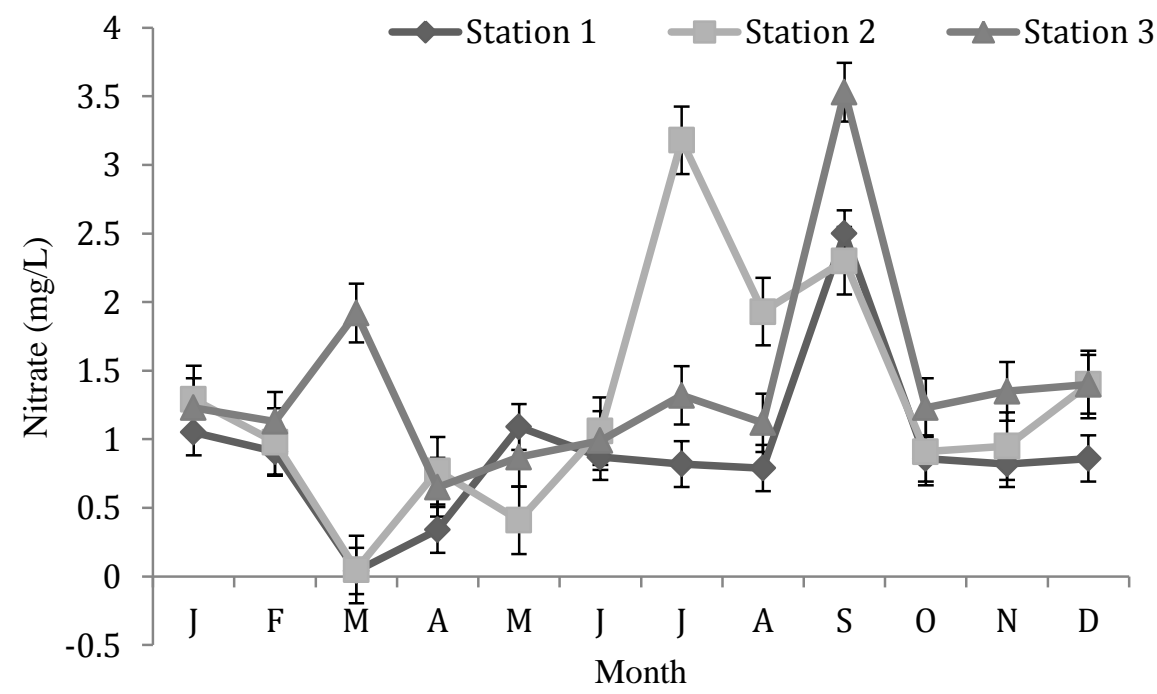

Figure 7a.Seasonal distribution of nitrate $( \pm$ SE) at KS river estuary, Miri, Sarawak. 


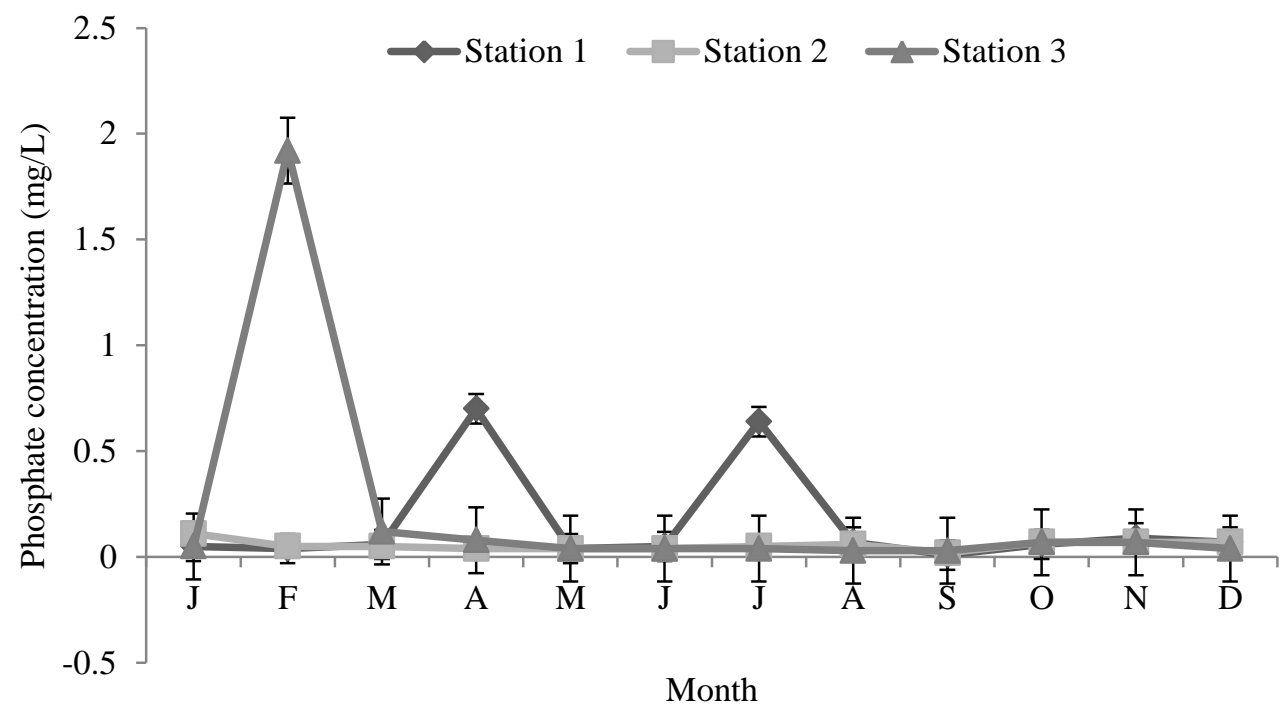

Figure 7b.Seasonal distribution of phosphate $( \pm$ SE)at KS river estuary, Miri, Sarawak.

Overall chemical index (Table 2) calculated from phosphate, suspended matter and dissolved oxygen was found to be 4.95 for this estuary. The water quality index showed seasonal changes. In the months of May to August (dry season)the water quality index ranged from 5.82-11.6i.e.,4.09 for March, 4.94 for November,1.59 for February, 2.84 for October and 2.63 for December.

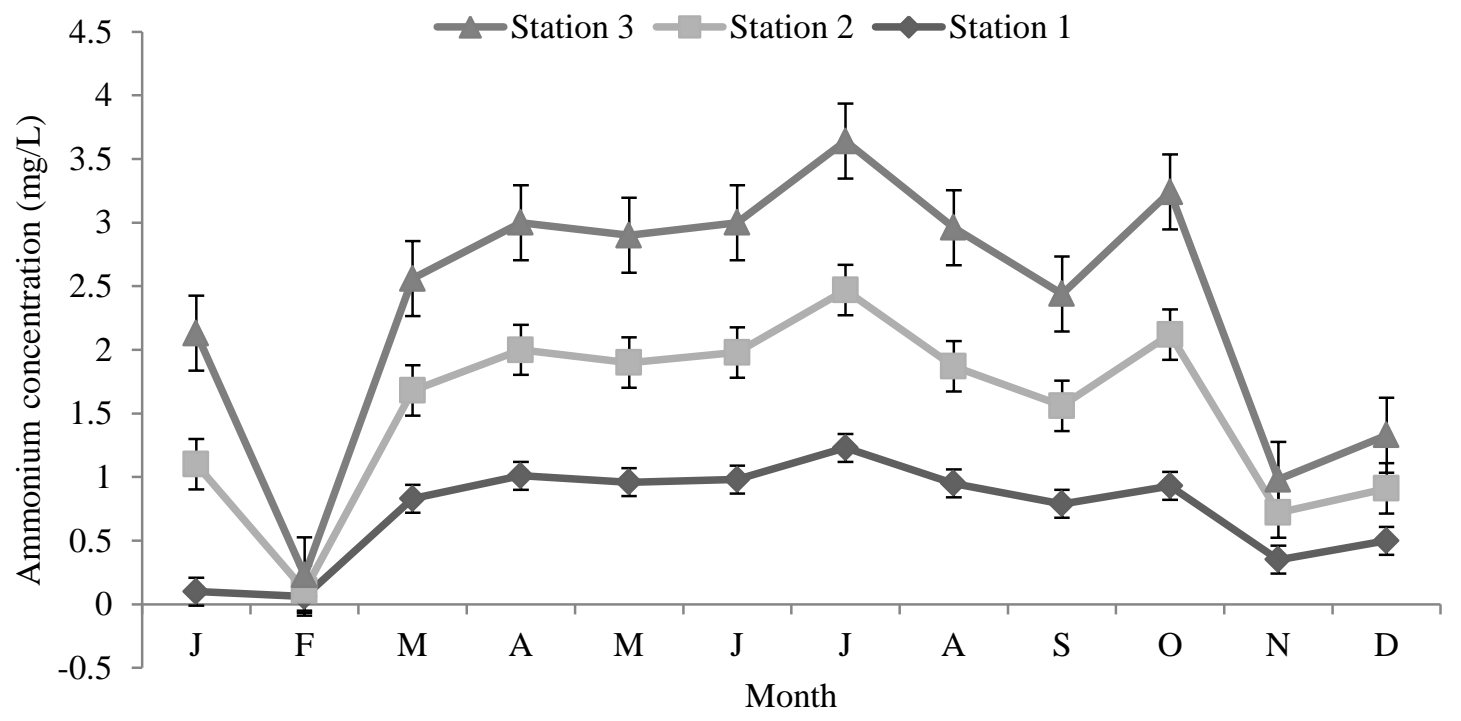

Figure 7c.Seasonal distribution of ammonium $( \pm$ SE) at KS river estuary, Miri, Sarawak. 
Malaysian Journal of Science 33 (1): 9-22 (2014)

Table 1. Pearson correlation coefficient matrix of different physical-chemical parameters (N=10) of KS river estuary, Miri, Sarawak.

\begin{tabular}{|c|c|c|c|c|c|c|c|c|c|c|}
\hline Parameters & $\mathrm{pH}$ & TDS & Salinity & Temperature & DO & Nitrate & Phosphate & Ammonium & Chlorophyll $a$ & Light attenuation \\
\hline $\mathrm{pH}$ & 1 & & & & & & & & & \\
\hline TDS & 0.83 & 1.00 & & & & & & & & \\
\hline Salinity & $0.84 * *$ & $0.95^{* *}$ & 1.00 & & & & & & & \\
\hline Temperature & 0.47 & $0.71 *$ & 0.75 & 1.00 & & & & & & \\
\hline DO & 0.53 & 0.59 & 0.45 & 0.13 & 1.00 & & & & & \\
\hline Nitrate & $0.99 * *$ & $0.83^{* *}$ & 0.84 & 0.47 & 0.53 & 1.00 & & & & \\
\hline Phosphate & 0.35 & $-0.26^{*}$ & -0.33 & -0.27 & -0.08 & 0.35 & 1.00 & & & \\
\hline Ammonium & 0.52 & $0.57 *$ & $0.60 *$ & 0.377 & 0.08 & 0.52 & -0.477 & 1.00 & & \\
\hline Chlorophyll $a$ & 0.08 & 0.08 & 0.07 & 0.05 & -0.23 & 0.09 & -0.06 & 0.30 & 1.00 & \\
\hline $\begin{array}{l}\text { Light } \\
\text { attenuation }\end{array}$ & 0.45 & $0.60 *$ & -0.66 & -0.76 & -0.11 & 0.45 & 0.58 & -0.61 & -0.09 & 1.00 \\
\hline
\end{tabular}

$* *$ Correlation is significant at $p<0.01 ; *$ Correlation is significant at $p<0.05$ 
Table 2.The mean value of Estuarine Water Quality Index (EWQI) for KS river estuary, Miri, Sarawak.

\begin{tabular}{llllllll}
\hline Month & PO $^{*}$ & IndexPO & SM $^{* *}$ & IndexSM & DO*** $^{* *}$ & IndexDO & TotalIndex \\
\hline January & 0.07 & 0.03 & 9.65 & 2.79 & 3.51 & 0.76 & 3.59 \\
February & 0.67 & 0.31 & 1.43 & 0.41 & 3.77 & 0.82 & 1.54 \\
March & 0.08 & 0.03 & 11.57 & 3.34 & 3.27 & 0.71 & 4.09 \\
April & 0.27 & 0.13 & 5.62 & 1.62 & 2.63 & 0.57 & 2.32 \\
May & 0.04 & 0.02 & 28.2 & 8.15 & 4.31 & 0.93 & 9.10 \\
June & 0.04 & 0.02 & 17.96 & 5.19 & 2.81 & 0.61 & 5.82 \\
July & 0.24 & 0.11 & 35.75 & 10.33 & 5.6 & 1.21 & 11.66 \\
August & 0.05 & 0.02 & 24.42 & 7.05 & 5.29 & 1.15 & 8.23 \\
September & 0.02 & 0.01 & 5.68 & 1.64 & 4.71 & 1.02 & 2.67 \\
October & 0.07 & 0.03 & 7.0 & 2.02 & 3.65 & 0.79 & 2.84 \\
November & 0.08 & 0.03 & 13.37 & 3.86 & 4.82 & 1.04 & 4.94 \\
December & 0.06 & 0.02 & 6.4 & 1.85 & 3.5 & 0.76 & 2.63 \\
\hline Average & & & & & 4.95 \\
\hline
\end{tabular}

With Score, 5 and above Very, good; 4, Good; 3, Moderate; 2, Poor; 1, Very poor *PO=Phosphate; *SM=Suspended Matter;***DO=Dissolved Oxygen

Table 3. ANOVA (Tukey'sstudentized range test)for physico-chemical parameters, nutrients and chlorophyll $a$ in relation to seasons $(\alpha=0.05)$.

\begin{tabular}{llllll}
\hline Parameter & DF & ANOVASS & Mean Square & F & Pr>F \\
\hline $\mathrm{pH}$ & 2 & 1.75 & 0.87 & 4.72 & 0.04 \\
Temperature & 2 & 14.71 & 7.35 & 6.09 & 0.02 \\
DO & 2 & 3.1 & 1.56 & 2.04 & 0.19 \\
Salinity & 2 & 524.23 & 262.11 & 30.83 & $<0.0001$ \\
TDS & 2 & 964.09 & 482.05 & 16.42 & 0.001 \\
Phosphate & 2 & 0.11 & 0.05 & 1.79 & 0.22 \\
Nitrate & 2 & 1.75 & 0.87 & 4.72 & 0.04 \\
Ammonium & 2 & 0.39 & 0.19 & 1.96 & 0.20 \\
Chlorophyll $a$ & 2 & 0.03 & 0.02 & 2.86 & 0.11 \\
\hline
\end{tabular}

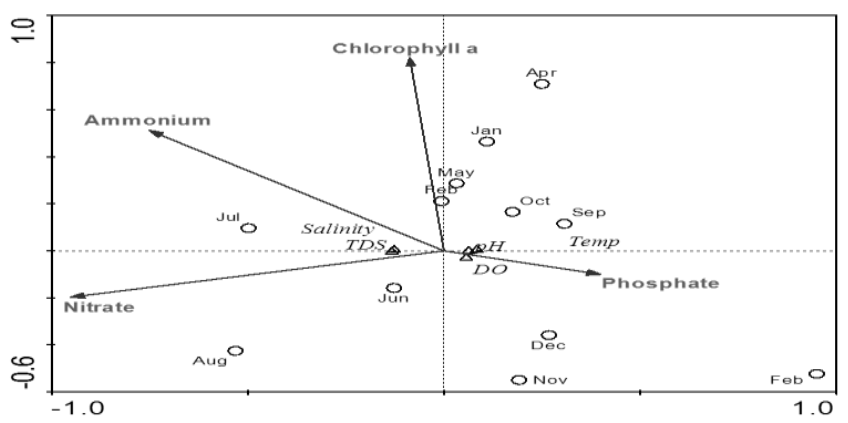

Figure 8.Canonical correspondence ordination of the physico-chemical parameters along with chlorophyll $a$ and nutrients at $\mathrm{K}$.

Sibuti (KS) river estuary in different months in the year.Bi-plots of the groups (occurrence frequency 33\%) and the environmental parameters show the seasonal variation and inter influence of parameters on each other's distribution. 
Pearson correlation coefficients showed significant positive correlation between nitrate and TDS $(\mathrm{r}=0.83)$, nitrate and $\mathrm{pH}(\mathrm{r}=0.99)$, ammonium and salinity (0.60), water temperature and salinity( $\mathrm{r}=0.74)$, temperature and, $\operatorname{TDS}(\mathrm{r}=0.71)$, phosphate and light attenuation ( $r=0.58$; Table 1$)$ in the Kuala Sibuti river estuary.

Canonical Correspondence Analysis (CCA) showed a positive correlation between ammonium and TDS.Phosphate showed negative correlation with Salinity and TDS(Figure 8). Seasonal changes also showed on nutrients and chlorophyll $a$ and other physico-chemical parameters. Canonical Correspondence Analysis (CCA) also showed a good association within nutrient and chlorophyll $a$ distribution with some physico-chemical parameters (Figure 8).

Seasonal variation among the physico-chemical parameters, nutrient and chlorophyll $a$ content was observed in this estuary (ANOVA,Tukey'sstudentizedrange test;Table 3).

\section{DISCUSSION}

Seasonal variability of different environmental features in an estuarine system demands an understanding of the freshwater discharge into the system, which is mainly controlled by the rainfall regime [14]. According toHossain et al. [15], yearly seasonal cycle is divisible into three distinct categories in Malaysia (Figure 10) i.e.,(1) wet season (September toDecember), (2) intermediate (January to April) and (3) dry season (May to August).

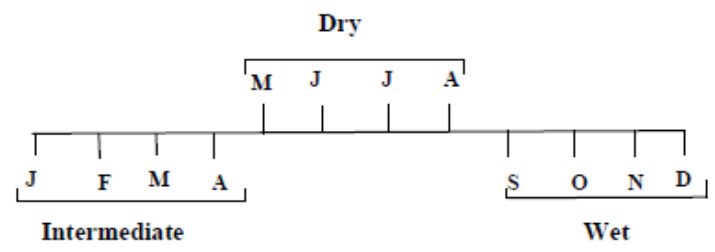

Figure 10.Seasonal division in tropical Malaysia

[15].

The variation in physico-chemical parameters of water of KS river estuaryshowed that the estuarine water characteristics changed with the monsoonalchanges. Salinity increased in dry season and restored nearlyin marine condition probably due to less fresh water discharge.A similar observation was found in the Mandovi-Zuari estuarine system in Goa [14].

Rainfall plays an important role in the seasonal cyclic phenomenon in the tropical environment and causes important changes in hydrographic changes in estuarine environments. In the studied area, the highest rainfall was observed during the wet seasonand the lowest in dry season.Rainfall showed a good association with the changesof salinity and water temperature in this estuarine system. Perumal et al. [16] also observed the same in an Indian estuary.

Water temperature changed in relation to the seasonal pattern, which could be due to the change of precipitation rate, solar radiation, evaporation, fresh water influx and cooling, mixing with the ebb and tidal flow from nearby neritic water. Usually the water temperature at mangrove ecosystem exceeds $24^{\circ} \mathrm{C}$ in the warmest month and $20^{\circ} \mathrm{C}$ or above in the coldest month [17]. However, in the present study, surface water temperature was always found above $27^{\circ} \mathrm{C}$ which indicates the nature of tropical climate.

Based on the salinity range (5.0-18.0 PSU), this estuary could be characterized as mesohaline in nature [18]. Salinity was found higher in the mouthof the estuary, which couldprobably be due to the direct entrance of sea water with less dilution of fresh water from upstream. It was observed that salinity increased in the dry season andthe onset of thewet season it started decreasing sharply. A similar observation was found in the Mandovi-Zuari estuary, Goa [14]) and Kaduviyar estuary, India [16]. Changes in the salinity of brackish water habitats such as estuaries, brackish water and mangrove are due to the influx of freshwater from land runoff, caused by monsoon or tidal variations. The distribution of living organisms somehow governs by the salinity, and variation of salinity caused by dilution and evaporation, which also be influencing factor in the distribution of fauna in the estuarine coastal ecosystems [19].

Generally, the seasonal variation of $\mathrm{pH}$ is attributed to some factors like sea water dilution by the influx of fresh water, removal of $\mathrm{CO}_{2}$ by photosynthesis through bicarbonate degradation, the reduction of salinity and temperature, and decomposition of organic matter [20,21]. According toDas et al. [22],the presence ofthe highest valueof $\mathrm{pH}$ in the dry season could be due to the penetration of sea 
water and high biological activity, while both the low and high water $\mathrm{pH}$ can be corrosive in nature [23].

In most of the cases TDS was found higher in station 1 and it could probably be due to the fact that this station is located at the mouth of the estuary where water turbulence was high due to in and out flow of sea water. Surface-runoff, stream flow and overland flow in natural waters also increase the TDS levels in water [24, 25]. The parameter like TDS, which is actually the dissolved particulates that absorb and refract light and colour, is responsible for absorption of light cause light attenuation.Inundation of fresh water discharge and bottom sediment play important role in governing the light penetration in any aquatic ecosystem [26]. The findings of the present study showed the same seasonal pattern of light attenuation that wasobserved in a tropical estuary, India [16]. Generally, light is the predominant factor for the growth of phytoplankton together with nutrient availability in the aquatic ecosystems [27, 28].

The oxygen concentration decreased with the increases of distance from the river mouth and temperature variation also showed the same pattern. The ability of oxygen to scavenge electrons from other molecules in key biological processes is of fundamental importance to life on the earth and as such the presence of oxygen in the aquatic environment has always been a key indicator of water quality [29]. Dissolved oxygen was found 2.1 $\mathrm{mg} / \mathrm{L}$ to $8.5 \mathrm{mg} / \mathrm{L}$ in Tapi estuary in the west coast of India [30] which is slightly higher than the present findings.

Reduction in chlorophyll $a$ concentration during wet season could probably be due to high precipitation. The concentration of chlorophyll $a$ found in this river estuary, to the some extent shows a similar value that of Kaduviyar estuary in India, which is reported at productive [16]. The concentration of chlorophyll $a$ was found higher in the intermediate season and lower in the wet season in K. Sibuti estuary. Usually, chlorophyll is considered as the principal photosynthetic pigment which has influence on productivity and represents the values of phytoplankton biomass.

Distribution of nutrients is mainly influenced by seasonal variation, rate of fresh water discharge, land run-off and tidal condition [20]. Possible sources of nitrate into the aquatic environmentare anthropogenic input, land runoff and oxidation of ammonia in a form of nitrogen to nitrite and consequently to nitrate. In the estuarine environment, nutrients are considered as vital components which play a vital role in growth, reproduction and metabolic rates of organisms. Seasonal distribution of nutrient was fluctuated, which maybe influenced by tidal condition and fresh water discharge. High concentration of ammonium in the aquatic environment can also be contributed by the death and subsequent decomposition of phytoplankton and also can be attributed by the excretion of ammonia by planktonic organisms [31]. Nutrients are a required resource for phytoplankton growth and reproduction in an estuarine environment [32, 33]. Concentrations of phosphate and nitrate are generally known to show a negative correlation with salinity [34]. Such relationship was observed between salinity and phosphate in this study. Generally, primary production andchlorophyll $a$ levels gradually decrease due to limited nutrient supplies [35, 36]. The association of nutrient and chlorophyll $a$ distribution in the K. Sibuti river estuary agreed with the findings of Qasim and Gupta [14] and Perumal et al. [16].

Estuarine water quality index (EWQI) was found very good during the month of May to August (dry season) followed by March and November probably due to less land runoff with less rainfall.The poor EWQI for the month of October and December (wet season)could probably due to the influence of heavy rainfall and river runoff in the estuarine system of K. Sibuti.

\section{CONCLUSION}

The spatial and temporal measurement of water parameters provided the opportunity to get a detail description of the water quality of the K.Sibuti river estuary. This estuary is bordered by pristine mangrove forests and experiencing low anthropogenic disturbances which could be the probable reason that kept the water quality in good condition. The estuary can be characterized as mesohaline in nature on the basis of salinity gradient and showed a good stand in terms of nutrient content and chlorophyll $a$. Mangroves dominated estuaries without anthropogenic disturbances are always found productive, and probably be an ideal ground for fisheries resources.Further study on productivity, fisheries potentiality and tropic linkage could establish a complete scenario of estuarine ecosystems and its functions of K. Sibuti. 


\section{ACKNOWLEDGEMENTS}

The authors acknowledge the Department of Animal Science and Fishery, UPM Bintulu, Sarawak Campusfor providing facilities and Malaysian Government for providing funds through E-Science, Project No. 04-01-04-SF1422. Special thanks to Mr. KhurshidAlam for making the study area map of K. Sibuti.

\section{REFERENCES}

1. Claridge, P.N., Potter, I.C.andHardisy, M.W.(1986).Seasonal changes in movements, abundance, size, composition and diversity of the fish fauna of the Severn estuary. Journal of the Marine Biology Association of the UK. 66(2):29-58.

2. Stowe, K.S.(1983). Ocean Science. John Wiley and Sons. New York. 673 p.

3. Junk, W.J., Bayley, P.B. and Sparks, R.E.(1989). The flood pulse concept in riverfloodplain systems. In: Dodge, D.P. (Ed.), Proceedings of the International Large River Symposium. Canadian Special Publication for Fish and Aquatic Science, pp. 110-127.

4. Ferreira, J.G. (2000). Development of an estuarine quality index based on key physical and biogeochemical features. Ocean and Coastal Management.4: 99-122.

5. Ibrahim, Z.Z., Moi, L.S., Abdullah,R. and Arshad,A. (1996). Classification of Malaysian estuaries for development planning. Aquatic conservations:Marine and Fresh Water Ecosystems. 6:195-203.

6. Mokhtar, M.B.,Almah, B.A. and Guan, L.Y.(1994). Water quality of Inanam river estuary and Ko-Neyalan tiger prawn aquaculture ponds in Sabah, Malaysia, Hydrobiologia.285:227-235.

7. MohdTahir, N.,Suratman, S., Shazili, N.A.M., Ariffin, M.M.,MohdAmin, M.S.,NikIskandarArif, N.F.M. andHasmizan WanSulaiman, W.N.(2008). Behaviour of water quality parameters during ebb tide in Dungun river estuary, Terengganu. Journal of Sustainability Science and Management. 3(1):1-10.
8. Chye, H.S. and Peng, T.S.(1997). The use of river plankton and fish in the water quality classification of Sungai Perai, Sungai Juru and Sungai Perils. Journal ENSEARCH. 10(2): 115-124.

9. Parsons, T.R., Maita,Y. and Lalli,C.M. (1984). A Manual of Chemical and Biological Methods for sea Water Analysis. 1st Edn.,Pergamon Press, Oxford.

10. Kitamura, H., Ishitani, H. Kuge,Y. and Nakamoto,M. (1982). Determination of nitrate in freshwater and sea water by a hidrazine reduction method. SuishituOdakuKenkyu. 5: 35-42.

11. Weatherburn, M.W. (1967). Phenol hypochlorite reaction for the determination of ammonia. Analytical Chemistry. 39:971-974.

12. Coombs, J. and Hall,D.O. (1982).Techniques in bio-productivity and photosynthesis. Pergamon Press, England, pp. 74-75.

13. Ott, W. R. (1978). Environmental Indices, Theory and Practice, Ann Arbor Science, Aim Arbor.

14. Qasim S.Z.and Sen Gupta,R. (1981). Environmental characteristics of the MandoviZuariestuarine system in Goa. EstuarineCoastal and Shelf Science.13: 557578.

15. Mahmood,H., Saberi,O., JaparSidik, B. andMisri, K.(2008). Biological cycling of micro-nutrients $(\mathrm{Cu}, \quad \mathrm{Fe}$ and $\mathrm{Zn})$ in Bruguieraparviflora dominated mangrove forest at Kuala Selangor nature park, Malaysia.Malaysian Applied Biology. 37(1): 63-68.

16. Perumal, N.V., Rajkumar, M.,Perumal, P.andRajaeskar, K.T.(2009).Seasonal variations of plankton diversity in the Kaduviyar estuary, Nagapattinam, southeast coast of India. Journal of Environmental Biology. 30(6):1035-1046.

17. Kathiresan, K.(2001). Ecology and Environment of Mangrove Ecosystems. Centre of Advanced Study in Marine Biology, Annamalai University, pp: 106-107.

18. Van Damme, S., Sturyf, E., Maris, T., Ysebaert, T. and Dehairs, F.(2005). Spatial and temporal patterns of water quality along the 
estuarine salinity gradient of the Scheldt estuary (Belgium and the Netherlands):results of an integrated monitoring approach. Hydrobiologia. 540:29-45.

19. Sridhar, R., Thangaradjou,T., Senthil Kumar,S. and Kannan,L.(2006). Water quality and the phytoplankton characteristics in the Palk Bay, south east coast of India. Journal of Environmental Biology. 27:561-566.

20. Saifullah, A.S.M., Kabir, M.H., Khatun, A., Roy S. and Sheikh, M.S.(2012).Investigation of some water quality parameters of the Burigangariver. Journal of Environmental Science and Natural Resources. 5(2): 47-52.

21. Rajaesgar, M.(2003). Physico-chemical characteristics of the Vellar estuary in relation to shrimp farming. Journal of Environmental Biology. 24:95-101.

22. Das, J., Das,S.N. and Sahoo,R.K. (1997). Semidiurnal variation of some physic-chemical parameters in the Mahanadi estuary, east coast of India. Indian Journal of Marine Science. 26: 323-326.

23. Boyd, C.E.(2000). Water Quality: An Introduction. Alabama Agricultural Experiment Station,Department of fisheries and allied aquacultures, Auburn University,USA,pp. 120121.

24. APHA (2005). Standard Methods of Water and

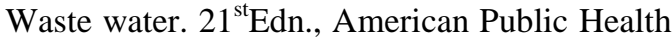
Association, Washington,DC.

25. Yisa, J. and Jimoh,T. (2010). Analytical studies on water quality index of River Landzu. American Journal of Applied Science.7:453458.

26. Sampathkumar,P. and Kannan,L. (1998). Seasonal variations in physic-chemical characteristics in the Tranquebar-Nagapattinam region, south east coast of India. Pollution Research.17:397-402.

27. Muylaert, K., Sabbe,K. and Vyverman,W. (2000). Spatial and temporal dynamics of phytoplankton communities in a temporal dynamics of phytoplankton communities in a fresh water tidal estuary (Schelde, Belgium). Estuarine Coastal and Shelf Sciences. 50: 673687.
28. Mann, K.H. and Lazier, J.R.N.(1996).Dynamics of Marine Ecosystems: Biological-Physical Interactions in the Oceans. Blackwell Scientific Publications, Boston.

29. Shane, O' Boyle,Georgina, Mc.D. and Robert, W.(2008). Dissolvedoxygen levels in estuarine and coastal waters around Ireland. Marine Pollution Bulletin. 58:1657-1663.

30. NirmalKumar, J.I., George, B., Kumar, R.N., Sajish, P.R. and Viyol,S.(2009). Assessment of spatial and temporal fluctuations in water quality of a tropical permanent estuarine system-Tapi, west coast of India. Applied Ecology and Environmental Research. 7(3):267-276.

31. Segar, K. and Hariharan,V. (1989). Seasonal distribution nitrate, nitrite and ammonia and plankton in effluent discharge area of Mangalore, west coast of India. Indian Journal of Marine Science. 18: 170-173.

32. Harris, G.P. and Baxter,G. (1996). Inter-annual variability in phytoplankton biomass and species composition in a subtropical reservoir. Freshwater Biology. 35:545-560.

33. Spatharis, S., Tsirtsis, G., Danielidis, D.B., Chi T.D. and Mouillot,D. (2007). Effects of pulsed nutrient inputs on phytoplankton assemblage structure and blooms in an enclosed coastal area. Estuarine Coastal and Shelf Science. 73:807-815.

34. Philips,J.(1972). Chemical processes in estuaries. In:R.S.K.Barnes and J.Green (Eds.),TheEstuarine Environment,Applied Science Publishers Ltd. London, pp. 35-50.

35. Kim, D., Choi, S.H., Kim, K.H., Shim, J.H., Yoo,S. and Kim,C.H.(2009). Spatial and temporal variation in nutrients and Chlorophyll $a$ concentrations in the northern East China Sea surrounding Cheju Island. Continental Shelf Research. 29:1426-1436.

36. Howarth, R. (1988). Nutrient limitation of net primary production in marine ecosystems. Annual Review of Ecology. 19:89-110. 